Information for citation:

Komissarova E. G., Krasnova T.V., Shershen T.V. Yuridicheskie formy roditel'skogo otnosheniya [Forms of Parental Legal Relations]. Vestnik Permskogo Universiteta. Juridicheskie Nauki - Perm University Herald. Juridical Sciences. 2017. Issue 38. Pp. 521-534. (In Russ.). DOI: 10.17072/1995-4190-2017-38-521-534.

UDC 347.634

DOI: 10.17072/1995-4190-2017-38-521-534

\title{
FORMS OF PARENTAL LEGAL RELATIONS
}

\section{E. G. Komissarova}

Perm State University

15, Bukireva st., Perm, 614990, Russia

ORCID: 0000-0003-4257-5673

ResearcherID: E-9302-2016

Articles in DB "Scopus" / "Web of Science":

DOI: 10.5829 /idosi.mejsr.2013.15.9.11540

DOI: $10.5829 /$ idosi.wasj.2013.24.01.13177

DOI: $10.17072 / 1995-4190-2015-1-64-72$

DOI: $10.17072 / 1995-4190-2016-32-185-192$

e-mail: grazhdanskoe.pravo@gmail.com

\section{T. V. Krasnova}

Institute of State and Law of the Tyumen State University

6, Volodarskogo st., Tyumen, 625000, Russia

ORCID: 0000-0002-3375-7443

ResearcherID: S-5442-2016

Articles in DB "Scopus" / "Web of Science":

DOI: $10.17072 / 1995-4190-2016-1-60-67$

DOI: $10.17072 / 1995-4190-2016-34-426-439$

e-mail: grazhdanskoe204@mail.ru

\section{T. V. Shershen}

Perm State University

15, Bukireva st., Perm, 614990, Russia

ORCID: 0000-0001-7158-3184

ResearcherID: H-4158-2016

e-mail: grazhdanskoe.pravo@gmail.com

Introduction: when researching the problems of parental legal relations, scholars usually employ the general concept of legal relations. The connection between parental legal relations and a closer type of relations - family legal ones - is not studied. The reason lies in the insufficiently developed scientific doctrine about family legal relations. As a result, the provisions of the doctrine relating to some particular types of family and parental legal relations remain undeveloped as well. In family law rhetoric, their essence is often hidden behind the familiar but scientifically unclear word combination "parental rights and obligations", which is often perceived as a mere formality necessary to form some judgments on its basis. Constituting the core of the so-called "parental right", the legal essence of this word combination is nearly always reduced to the question of whom and how to oblige and force for the rights of the parent-child legal relations participants to be respected. Purpose: to lay the foundation for creation of the necessary theoretical groundwork for the problem of parental legal relations, taking into account the necessary theoretical and methodological premises. Methods: the research is based on general scientific methods (formal and dialectic logic, comparative law, interpretation) and 
the legal dogmatic method of cognition. Results: existence of a well-developed theory of family legal relations will allow for formation of the appropriate theoretical and methodological foundations for studying the theory of parental legal relations as their variety. In order to ensure progress in the development of scientific issues concerning parental legal relations, the authors propose to distinguish between rights in personam with obligations corresponding to them and absolute rights as perfect rights realization of which is not associated with assigning anybody to obligations.

\section{Keywords: family legal relations; conceptual and methodological framework of science; forms of legal regulation; rights in personam; absolute rights; parental care \\ Information in Russian ЮРИДИЧЕСКИЕ ФОРМЫ РОДИТЕЛЬСКОГО ОТНОШЕНИЯ}

\section{Е. Г. Комиссарова}

Доктор юридических наук, профессор,

заслуженный работник высшей школы РФ, профессор кафедры гражданского права

Пермский государственный национальный исследовательский университет

614990, Россия, г. Пермь, ул. Букирева, 15

ORCID: 0000-0003-4257-5673

ResearcherID: E-9302-2016

Статьи автора в БД «Scopus» / «Web of Science»:

DOI: 10.5829 /idosi.mejsr.2013.15.9.11540

DOI: 10.5829 /idosi.wasj.2013.24.01.13177

DOI: $10.17072 / 1995-4190-2015-1-64-72$

DOI: $10.17072 / 1995-4190-2016-32-185-192$

e-mail: grazhdanskoe.pravo@gmail.com

\section{Т. В. Краснова}

Кандидат юридических наук, доцент, и. о. зав. кафедрой гражданского права и процесса Институт государства и права Тюменского государственного университета

625000 , Россия, г. Тюмень, ул. Володарского, 6

ORCID: 0000-0002-3375-7443

ResearcherID: S-5442-2016

Статьи автора в БД «Scopus» / «Web of Science»:

DOI: $10.17072 / 1995-4190-2016-1-60-67$

DOI: $10.17072 / 1995-4190-2016-34-426-439$

e-mail: grazhdanskoe204@mail.ru

\section{Т. В. Шершень}

Кандидат юридических наук, доцент, заведующая кафедрой гражданского права

Пермский государственный национальный исследовательский университет,

614990, Россия, г. Пермь, ул. Букирева, 15

ORCID: 0000-0001-7158-3184

ResearcherID: H-4158-2016

e-mail: grazhdanskoe.pravo@gmail.com

Введение: обращаясь к исследованию проблем родительского правоотношения авторы часто опираются лишь на общеправовое понятие правоотношения. Связь родительского правоотношения с более близким - семейным правоотношением не исследуется. Причина - в неразвитости научного учения о семейном правоотношении. Как следствие, неразвитыми остаются и необходимые доктринальные положения, относящиеся $\kappa$ отдельным разновидностям семейного правоотношения в целом и родительского в частности. В семейно-правовой риторике их суть часто скрывается за привычныли и, как оказалось, для науки весьма безликим сочетанием "родительские права и обязанности», воспринимаемым часто в качестве одной лишь необходимой формальности для последующих суждений. Составляя стержень так называемого "родительского права», 
правовая сущуность этого сочетания практически всегда сводится к вопросу о том, кого и как обязать, заставить, чтобы права участников детско-родительского отночения были соблюдены. Цель: положить начало созданию необходимого теоретического задела по проблеме родительского правоотночения с учетом необходимых теоретикометодологических предпосылок. Методы: при написании статьи использовались общенаучные методы исследования (формальной и диалектической логики; сравнительного правоведения, интерпретации) и частнонаучный юридико-догматический метод познания. Результать: наличие развитой теории семейного правоотношения позволит сформировать надлежашие теоретико-методологические предпосылки для исследования теории родительского правоотношения как его разновидности. Для того чтобь обеспечить научное движение в проблематике теории родительского правоотночения в его полноценном теоретическом объеме, авторы предлагают различать субъективные относительные права с корреспондирующими им обязанностями и права абсолютные как права признанные, реализация которых не связана с закреплением за кем-либо обязанностей.

Ключевые слова: семейное правоотношение; понятийно-методологическая основа науки; юридические формы правового регулирования; субъективные относительные права; абсолютные права; родительская забота

\section{Introduction}

The scientific problem embodied in the title of the article has not been problematized and has not yet been studied in family legal doctrine in this kind of formulation. The doctrinal interest in the problem of parental legal relations is shifted to studying parental rights and obligations, and not always in the context of their correspondence to each other. The doctrine rarely directly refers to the parental legal relations theory [21]; and for the time being, in spite of the fact that in the theory of family law some methodological issues are beginning to arise $[4,7]$, no satisfactory methodological approaches to the study of this subject matter are clearly noticeable.

The article is devoted to creation of that part of the necessary theoretical groundwork that will allow for the development of the doctrinal platform to solve the issue whether it is correct to reduce any consequences of legal assessment of social relations with participation of parents and children only to the concept of legal relations, or other legal forms are permissible for this purpose.

\section{Parental Legal Relations as a Form of Family Legal Relations}

The review of the available scientific papers closely connected to parental legal relations leave a lingering impression that each of these publications is to some extent influenced by the ideas of seeming obviousness of these relations, their ordinariness and at the same time social significance. The word combination "parental rights" is often used with different shifting in emphasis, influenced by the scientific term "parental obligations law", which entails abstract speculations about certain parental rights and obligations, not particularly caring about the fact of who has received which ones from the legislator. The fact they are law-stipulated turns out to be sufficient.

As for the methodological aspect of the current doctrinal appeals to the issues of parental legal relations, it has been so far limited by the use of the "well-formed formula" of the general legal relations theory as the universal model of legal regulation, where it is necessary to include generally established parameters of parental legal relations: subjects, objects, rights and obligations. As a result, the general scientific picture of parental legal relations looks very simple and uniform: initially the actual live relationship with participation of parents and children that does not contain any elements is formed up, then in the process of research this live relationship "turns" into the legal relations by "including" categories from the general legal theory about subjects, objects, rights and obligations. The general theoretical pattern of legal relations is thus created, being as a rule characterized with legal uncertainty of the participants' rights and obligations in terms of their confrontation. Then the epithet "parental" is added thereto. As for the substantive analysis of the rights and obligations of the participants of parental legal relations, it usually differs little from the common teaching logic, which quite 
formally reveals the genuine connection of family legal rules with the regulated parental relations. The logic of identifying parental legal relations as a specific category out of the generic category represented by family legal relations turns out to be unstudied, as well as the coordination of these two kinds of legal relations.

It would be wrong to say that such doctrinal analytics of parental legal relations eventually turns out to be irrelevant. Taking into consideration that the state and law theory forms the general scientific bedrock for all jurisprudence, this analytics does perform some methodological function, albeit insignificant. However, when proceeding from and based on the theory of family legal relations, including the point of splitting this legal relation into the varieties, such approach is clearly insufficient for a valid scientific argumentation. In addition, this more mechanical combinatorics, not associated with the intra-branch theory of legal relations in family law, can only maintain the level of development of the doctrine of parental rights and obligations and parental legal relations that was reached by the Soviet family law science [19].

There is no normative visualization of family legal relations and their varieties in the Russian family legislation. Such serious ground for qualified involvement of the parental legal relations theory into the research field can be found for example in the family legislation of the Republic of Belarus, with which Russia has not only the common Soviet scientific past, but also a common history, culture and geographical location, as well as the prevailing opinion that family law is a separate branch of law.

Provisions of the Marriage and Family Code of the Republic of Belarus use the construction of legal relations in two chapters of section III "Family": "Personal Non-Property Legal Relations in the Family" (Chapter 10) and "Property Legal Relations between Parents and Children" (Chapter 11) ${ }^{1}$. It is debatable if inclusion of certain standards on parental and children's rights and obligations is reasonable in these chapters. However, one can surely see that the provisions of the family legislation are

\footnotetext{
1 Marriage and Family Code of the Republic of Belarus (adopted by the House of Representatives on June 3, 1999, approved by the Soviet of the Republic on June 24, 1999.) // National legal internet-portal of the Republic of Belarus: http://zakon.by. 16.07.2017.
}

oriented towards professionals able not only to bring the chapter's names into correlation with the articles placed in them, but also not to "separate" rights in personam from subjective obligations within the framework of legal relations.

The insight into the doctrinal state of the parental legal relations issue, easily allows us to see the "gap" in the form of absence of a developed theory of family legal relations in family law science. The attempt to turn to research papers on family legal issues $[3 ; 13 ; 20]$ has come to nothing. There are no papers with family legal relations being the subject matter. Rare doctrinal efforts represent intermediate/episodic judgements on family legal relations, coming out to be not the strongest background for derivative issues. As for the concept of "family legal relations", it is used by scientists as a given and well-known fact that originates from the understanding that since the concept of legal relations has been developed and is used in legal science, then it should be used in family law science as well.

The marked detachment of the family law science from the issue of family legal relations does not allow for comprehending the vastness of the phenomenon and the actual theoretical volume mastering of which has helped to create a methodologically precise approach to studying its varieties. For this reason, these varieties of family legal relations - parental, adoptive, matrimonial and others, singled out by the intent of a certain researcher, are considered to be existing and are used without any meaningful scientific reference points, remaining separated and actually not related to each other, and most significantly, without a well-developed theory of family legal relations being their common "root".

The number of such research papers is increasing but proper methodological framework has not been created for them yet in the doctrinal space of family law. The ideas of O.S Ioffe, one of the first scholars addressing the issues of family legal relations, E.M. Vorozheykin, who indicated that "family legal relations, do not just repeat the features of the actual social relations forming the basis for them" [2, p. 44], A. I. Pergament remain undeveloped. Accordingly, the issues closely connected with the problem of family legal relations, such as family legal standing, family rights and their varieties, limits of exercising different kinds of family rights, are in the state of virginity today. Mean- 
while, it cannot be excluded that the theory of family legal relations with its all-sufficient scientific and theoretical framework could become one of the reliable grounds for the modern family law science with its unofficial status of the "scientific provincial" and partly cracked independence, which once won most of scientific minds, but began to lose its followers in modern jurisprudence [1, p. 76; 9].

Although the problem of family legal relations doctrine and its classification in the family law science was identified as back as at the times of Soviet jurisprudence, scientific enthusiasts working on the issue of family legal relations have not appeared yet. That is why the habitual ease in using of the category of family (as well as parental, adoptive, and matrimonial) legal relations has not developed into a profound scientific interest. Moreover, being actually in the condition of doctrinal "freezing", this subject matter is even removed from some basic textbooks for universities. By comparison, more than 100 years ago (1908), without paying attention to the general issues of family rights and legal relations specifics, K.I. Malyshev presented family law proceeding from the general rules of a marital union.

The doctrine of family legal relations and their varieties forms an integral part of the conceptual and methodological groundwork for family law science, along with such fundamental concepts as the subject, method, basic principles, sources of family law; therefore, the conceptual and legal specification of this family legal formula "gene" in the doctrine of family law is also a scientific task of high importance.

Protecting its independence and selfsufficiency, and at the same time not developing its own scientific foundations, one of which is undoubtedly the theory of family legal relations, the doctrine unwillingly retards improvement of the structure of the Family Code of the Russian Federation (RF FC). It is known that this act of codification has a very simplified internal structure, unsubordinated to systematization of its provisions according to the Pandects. Having once passed beyond the traditional civil law boundaries and having stayed beyond them by the moment of the RF FC adoption in 1995, the legislator turned out to be uninvolved in this traditional approach, belonging to the "identity" of almost all codification acts of the Continental law system. As a result, the RF FC has no General Part, in which, following the example of all other acts of branch codification, one could see a "doctrinal echo" of the developed theory of family legal relations - of course not through their definition but with the help of their meaningful components, such as family legal standing, grounds for arising, change and termination of legal relations, procedure and limits of exercising family rights and family obligations etc. More and more often attention is paid in the theory of family law to the unjustified absence of the subdivision of the RF FC provisions into the General Part and Special Part $[13,24]$.

It seems to us that maintaining the doctrinal indifference to the theory of family legal relations sets the family law science aside from the required theoretical and methodical reference points, allowing for the maintenance of a more traditional and trivial level of knowledge about parental legal relations, notwithstanding all scientific knowledge about them. According to V.I. Vernadsky, it is the knowledge that "demonstrates a clear progress". As is commonly known, such progress can only be achieved through objective, well-reasoned, substantiated knowledge aimed at meeting the future.

\section{Parental Legal Relations and Absolute Rights in the Sphere of Parental Care as Different Forms of Regulation of Legal Relations with Participation of Children (Problem Setting)}

The multi-faceted theory of legal relations, which has proved to be useful for the entire jurisprudence, was originally developed in the 1940-60s in the theory of civil law, being named by academic contemporaries a "brilliant theoretical discovery, forming the nucleus of the modern civil law science according to the Pandects " [15, p. 150]. Initially existing as a narrow normative science, it gradually gave way to the extended approach, when along with the in-depth study of specific elements of legal relations, more attention was given to the study of system-wide connections of legal relations with other legal phenomena included in the scope of doctrinal attention under the name of legal standing, limitations and restrictions as well as encumbrances as exceptions from legal possibilities, secondary rights. However, it should be mentioned that the idea of the impossibility to reduce legal regulations to the influence of legal instructions through legal relations was already substantiated in Soviet jurisprudence [23, pp. 205-206]. 
Absence of a developed theory of family legal relations does not allow the family law doctrine to turn to cognizing those alternative forms of legal regulation of lawful behavior of family relations participants that do not fit in the model of legal relations. Considering family law as a synonym of family legal relations $[18$, p. 8$]$, the representatives of family legal science continue thinking in terms of only one legal relations category, and thus seek to find solutions for all legal issues concerning different types of family relations within only one theory of legal relations.

If to continue speaking about parental and children relations from this perspective, one can see the doctrinal difference that appears from the impossibility to establish the necessary correspondence that should accompany rights and obligations of participants of any legal relations. This is exactly how the general theoretical propositions are set up concerning legal relations being an ideal and closed category, whose viability depends on availability of two kinds of categorical connections referring to the pair type. The first kind is the rule of law and legal relations. The other one is the abstract right and abstract legal obligation in their correspondence. When discussing parental relations, the first type of connection is always revealed, while the second one can be not always established. As far as for family law, whose modern "breathing" is only connected with legal relations, the fact of unestablished correspondence equals the fact of "exclusion" of the respective relations from the field of legal impact, the efforts of scientists are focused on searching for this actual correspondence. It was begun in the times of the Soviet family law science, when a doctrinally considered theory of legal relations appeared in jurisprudence. According to this theory, permitted behavior is simulated only by a right with the corresponding obligation. Unwilling to exclude parental relations from the general range of legal relations, scholars strived to find these coordinating connections. As O.S. Ioffe stated, "the parents' right to bring up children necessarily corresponds with the children's obligation to obey the influence" [5, pp. 238-239]; the authors of the commentary to the RSFSR Marriage and Family Code stated that "parental rights at the same time constitute obligations for brining up children" [6]. The Russian family law science is a successor of all these ambivalent views. It has added very little to the previous approaches and has not reduced the difficulties related to singling out the corresponding interconnection between rights and obligations within the framework of parental legal relations. As A.M. Nechaeva pointed out in this regard: "If we refer to the literature on family law, it is not difficult to see that the connection between the rights and obligations existing in the RF FC, and being in perfect step, is understood differently" At this point, the circulation of scientific ideas comes to the end.

The reason for such centrifugal approach to the theory of parental and children relations, developing from "itself", lies not only in the absolute lack of scientific development of the theory of family legal relations and parental relations as their variety and the absence of definite theoretical and methodological approaches to this scientific problem, but also in the exclusion of other legal form of regulating relations involving parents and children from the modern doctrinal perceptions.

As L.I. Kask emphasized, exercising of law rules outside legal relations means unhindered use of legal rights and conscious observation of legal obligations without any particular connections and relations between the subjects of law [17, p. 465]. Thus, scholars believed that legal regulation might be connected with exercising of general and absolute rights, the scope of which was precisely stipulated by an act of legislation or another source of law. These rights, being outside of legal relations, also serve the purposes of legal regulation.

Definition of absolute rights in terms of their meaning for the man himself was given as back as in 1899 by a Russian political scientist N.M. Korkunov. Among other things, he stated that these rights are inherent ones, independent of the state, unconditioned and unchanged, and for this reason indefeasible for the government. There have already been some modern examples when regulatory capabilities of the absolute rights theory (not without the doctrinal contribution) have been implemented within the framework of (civil) legislation (art. 150, 1226, 1229 of the RF CC). This does not mean that the absolute rights theory needs no more development. There is some debate about the possibility of absolute rights exercising outside legal relations [14], but without the family legal doctrine as yet. 
Taking into account the civil law origin of family law, we consider it possible to use the absolute right construction for the purposes of family law regulation.

Reference to the doctrinal groundwork developed in the Russian, Soviet and partly modern doctrine of family law, allows us to clearly see the ambivalent approach of the science to evaluation of rights arising within a family, with engagement of the signs of absoluteness and relativity of those rights. As G.F. Shershenevich stated, a marital union creates two kinds of family rights, where the "personal power right" is absolute and the "right to be supported" is relative D.I. Meyer also paid attention to the non-uniformity of the regulation of family legal relations, considering that relations appearing in connection with parental power should be "placed" into the section of state law. A.I. Pergament noted that the essence of parental right as the absolute right consists in the "behavior of the right holder but not in his requirements of particular behavior from other people" In the modern family law science, having legislative confusions in terms of the rights concerning parenthood and childhood, there is lack of clarity in interpretation of the terms "right" and "legal power", which hinders comprehension of parental powers in respect of the family legal relations [10]. Thanks to these premises, in the family law science there appear judgments on the "complicated right" (M.N. Maleina) and the "existence of a set of rights in family relations with elements of the public order", claiming further doctrinal attention [16, p. 54].

Moreover, foreign legislation, having become public, and the theoretical knowledge which ensures its development in the continental law system leave much to be said about the different kinds of family rights in the field of parenthood.

In order to regulate parental relations, European countries at the national level use legal constructions and models conditioned by the significant influence of their traditions as well as of family law retrospectives. In a number of European countries, the concept of parental power still remains the basis of parental relations regulation. However, it is no longer complete and unlimited as it was envisaged by the Roman civil law in respect to the father's power. Over the second half of the $20^{\text {th }}$, this concept underwent natural legislative modernization.
For example, in Denmark due to the legislation changes in 1985 the content of parental power implies not only parental rights to solve all issues concerning the child but also the obligations to protect the child, take care of him, including custody, as well as to participate in the relevant legal and financial relations purely on the basis of the child's interests and needs [29, p. 9]. In the Napoleonic Code of 1804, initially the institute of father's power (art. 371-385 of the French CC) included very wide powers of the father in relation to his child till his adulthood. Taking care of the minor was regulated through the form of parental custody (art. 389450 of the French CC). As a result of amending the Civil Code of France by the laws of 1970 and 1983, parental equality in childcare was established. Thus, the institute of father's power was greatly transformed. Currently parental power includes a range of rights and obligations serving the child's interests, namely, taking care of the child, maintaining personal relationships, determination of the child's place of residence, providing education, being the child's legal representatives, supporting the child, managing property, bearing liability for damage caused by the child [34, pp. 184-186].

There is a modified construction of parental power in Italian legislation, which inclusively unites a bundle of rights and obligations (mere parental power) and liability as an attribute of this power (Title IX, Book I of the Italian CC). In the doctrine, parental power is considered as a civil law institution that should guarantee the child's moral and material well-being and exercising parental powers and authority exclusively in the interests of the child [29, pp. 14-15].

For the purposes of the unification of legal regulation of relations between parents and children, the EU countries apply the European Union Council Regulation No. 2201/2003 of 27 November, 2003, concerning jurisdiction and the recognition and enforcement of judgments in matrimonial matters and matters of parental responsibility (Brussels II Regulation). This act covers only civil issues concerning exercising parenthood (but the so called public measures, such as placement of the child in a substitute family and application of protection institutions provided for by the national laws remain beyond the act) [35, pp. 19-20]. At the same time, Brussels II Regulation uses the term 
"parental obligations" to cover all rights and obligations in relation to the person or the property of the child vested in the natural or legal person by a court decision, operation of law or binding agreement, including determination of the rights to live together with the child and to bring up the child as well as the right to have access to the child. In the opinion of researchers, inclusion of this category and its definition into the act aimed at resolution of conflicts of law between the EU state-members is very important for delineation of the field of substantive law application [26, p. 290]. It also creates general principles for the application of categories used by judges and being common for the EU legislation and national legal systems of its state-members [25, p. 165].

It is widely accepted that German legislation is headmost in the sphere of differentiation and systematization of parental and child's rights. Family legislation in Germany, renouncing autonomy of family law and considering it a part of civil law, builds legal regulation of parental relations using the absolute right theory. At first glance, there is little difference between German and Russian legislation in this part except for the fact that "there are no such official wordings as parental rights and obligations" [11]. Yet still some differences exist and deserve special attention because they arise not only from the ideological content of German family legislation based on the keynote "children grow up to become people" (aus Kindern werden Leute), but also from its constructive peculiarities, established with the use of both the category of legal relations and doctrinal achievements in the theory of absolute rights.

In Germany, childcare is considered to be the natural right and basic constitutional obligation of parents. Thanks to this premise, the legislator has implemented the regulatory possibilities of absolute rights in the laws that establish the rules in the field of parental care. As it is stipulated in Article 6 of Section I of the Basic Law of Germany, "taking care of and bringing up children are the natural rights of parents and their basic obligation. The State observes and controls this activity" (Pflege und Erziehung der Kinder sind das natürliche Recht der Eltern und die zuvörderst ihnen obliegende Pflicht. Über ihre Betätigung wacht die staatliche
Gemeinschaft) ${ }^{1}$. The meaning of this rule determines the forms of legal regulation of relations with participation of children and parents. The legislation is oriented towards both the construction of parental legal relations and the legal form of the absolute right in terms of everything that concerns parental power, having transformed into a codified formula of parental care in the German civilized society. Accordingly, Section 4 of Book 4 "Family Law" in the rules of the German Civil Code (hereinafter referred to as the GCC) is named General provisions on legal relations of parents and chil$\mathrm{dren}^{2}$. The constructions of the relations are applied to all various cases of assigning a family name to the child ( $\S \S 1616-1618)$, mutual assistance and respect of parents and children ( $\S 1618$ a), the child's help in housekeeping and ( $\$ 1619)$, the child's expenses for parents' housekeeping (§ 1620 ), property relations connected with division of parents' property ( $(1624)$ and the child's property. The rules of parental care, out of their understanding as legal relations, are placed in a separate more voluminous section of Book 5 "Parental Care" (§§ 1626-1698b). The introductory provision of the section is named "Parental Care: Fundamental Principles". Not using the term "legal relations", the legislator establishes that "parents must and have the right to take care of the minor". Parental care includes childcare (care of the person) and taking care of the child's property (property care)". The content and limits of childcare are formulated in $\S$ 1631: "Childcare includes, for example, the right and obligation to take care of the child, to bring up the child, to look after the child and to determine the child's place of residence (1). Children have the right to be brought up free from violence (2). The family court is obliged to support parents in their childcare where appropriate on application (3)". Violation of these rights by any person is qualified by the German legislator as impermissible actions according to $\S 823$ of the German Civil Code [40].

In some academic texts, along with the term "parental care" the term "parental responsibility"

\footnotetext{
${ }^{1}$ Das Grundgesetz (GG) ist die Verfassung für die Bundesrepublik Deutschland: http://www.bundestag.de/parlament/aufgaben/rechtsgrundlagen/grundgesetz/gg_01/245122.

${ }^{2}$ Grazhdanskoe ulozhenie Germanii: Vvodny zakon k Grazhdanskomu ulozheniyu [Bürgerliches Gesetzbuch Deutschlands mit Einführungsgesetz]: per.s nem / sost., vved. V. Bergmann; nauch. red. T.F.Yakovleva;. 4-e isd., pererab. M., 2015. $888 \mathrm{~s}$.
} 
(die elterliche Verantwortung) is used [30, p. 527]. This category is used for different purposes in the Act on Jurisdiction of Non-Contentious Matters (FGG), valid from 1990 till 2009 (as a result of the reform, this act was replaced by the Act on Proceedings in Family Matters and in Matters of NonContentious Jurisdiction (FamFGG) [37, p. 48].

On the whole, it is typical of German legislative practice to take into account provisions of fundamental doctrines. However, notwithstanding these immensely developed doctrinal provisions of German law on absolute rights, the division of rights into absolute and relative ones is not accepted as the base of civil codification of Germany, a part of which is constituted by the rules of family legislation. However, in modern juridical literature and in the commentaries of German scholars to the provisions of parental care, the importance of the theoretical aspect of singling out absolute rights, is emphasized; with parental care occupying its own place among those rights. Understanding of this theoretical provision provides the correct comprehension of the systematics of the German Civil Code provisions [41, p. 3].

Characterization of parental care as an absolute right implies that it is a personal, uninheritable right excluded from circulation. Contextually, the parental care right is limited by the duty to observe the child's interests and not to endanger his or her wellbeing, otherwise intervention of the state is possible in order to regulate the activities of the right holders [42, p. 156]. In addition, being an absolute right, in the civil law system the parental care right enjoys protection from the intervention of third persons, which assumes not only the right to require taking the child back by parents or one of them from any person who illegally keeps the child $\S 1632$ (1) of the German Civil Code, but also the right to claim damages according to $\S 823$ (1) of the German Civil Code [37, p. 436].

The historical backgrounds for introducing the concept of parental care were also laid down in the Russian prerevolutionary legislation, which actively used the term "parental power", understood as a special power arising from the natural relationship not for the sake of itself but as a natural consequence of such relationship, in which, according to K. P. Pobedonostsev «protection and guidance of the persons under the power are required». The retrospective analysis of essential characteristics of this category would allow for considering it as a genetic form of the legal construction of parental care. However, this is not what we have yet.
Abstraction in the form of such a conceptual construction as an absolute right is not considered to be an evil of the Romano-Germanic jurisprudence, and moreover is compatible with the theory of generations of human rights, including those rights that have already received or are only beginning to receive international legal recognition [39].

In the countries of continental law, the concept and value of the theoretical division of rights into relative and absolute ones are mainly communicated by the doctrine, while in common law this function is performed by the law enforcement practice, where another approach is applied to formulating rules of parental law [32, 33, 34]. For example, in Great Britain, according to the existing legislation and case law, children get "parental protection" from the date of birth, and the legal model of social relationship is built on the basis of obliging parents towards children without any obligations on the part of the child [27, pp. 1-2]. In particular, in the Children Act of 1989 (Part1, Section 3) the organizational concept of the rights of parents and children was replaced, taking into account the key function of parenthood as a social institute - to bear the responsibility to bring up the child and ensure interests of the child to the fullest extent possible. Instead of the construction of parental "rights and obligations", previously used in the Children Act of 1975, the concept of parental responsibility was introduced. The responsibility means all rights, obligations, authorities, responsibilities and power vested in the parent by law in relation to the child and his or her property [24, pp. 23-24].

There is no list of parental and children's rights and obligations in the legislation of these countries. Such approach is to a large extent determined by the peculiarities of the legal system: English family law focuses on pathologies of family life, and that is why the court is only involved at the stage "when things in the family are going wrong, the relationships are destroyed and there are controversies" [31, p. IXIII]. At the same time, based on the analysis of regulatory legal acts (e.g. the Children Act of 1989) as wells as precedents, in the English doctrine a set of parents' rights and obligations towards their children has been singled out. Among those are the possibility to raise and bring up the child, to have contacts with the child, to protect and support the child, to give a name to the child, to solve the issues of the child's education and religious background, his/her leaving the United Kingdom and emigration, healthcare, to exercise the powers and authorities concerning the child's property and 
transactions with it, to be the child's legal representative etc. [27, pp. 337-338].

The indicated difference of the legal thinking in the countries of civil and common law, however, does not exclude that the common law recognizes such division within the meaning generally accepted by European lawyers - as the right that differs from the relative right by the number of obligors.

Unlike the international legislation and the doctrine and law enforcement practice nourishing this legislation, Russian juridical doctrine and the law executor have only one thing to do with the child-parent issue, speaking with the words of M. M. Vinaver, the prerevolutionary civilist and political activist: "to slowly silt through the thankless letter of the law, drop by drop, comprehending the things that have already been the common achievement of the civilized world for a long time". The only exceptions are the well-developed constructions concerning the issues of property interaction between parents and children, what cannot be said about interaction regarding personal nonproperty rights. Here semantics of many categories used by the legislator is not entirely clear and fully geared with the international and constitutional legislation, corresponding to the time that has come the time of recognition of the child's right to be cared by parents and the parents' right to bring up and take care of the child, with consideration of the social role of these rights.

The analysis of correlation of these provisions to the RF Family Code and the doctrinal state of the issue reveals their insufficient ideological correspondence to the established international and constitutional recognition. As for now, only the number of rights singled out is increasing.

No matter how long (and disparate) the list of rights of the parental relations participants is, it is not difficult to see that the rules of the Russian family legislation do not produce the axiom of the inherent value of certain types of rights which are related to the basic nature of human rights, conditioning their explicit recognition by the state. They are more likely understood as service elements in the current mechanism of the implementation and protection of parents' and children's rights.

In order to avoid such understanding, there is a need in differentiation of the rights of parents and children into absolute and relative ones. Otherwise, the habitual understanding will work: since there is a right prescribed (not recognized) by the law, then there shall be a prescribed obligation, "strengthening" this right and ensuring its exercising.
The division of rights into absolute and relative ones does not create difference in their significance and does not entail their opposition in the sense of their advantages. Although both have the corresponding obligations, the structure of these rights is different. That is why the social difference of the rights is expressed in varying degrees of their significance for the society. The absolute right is connected with the general proscription to entrench on it; this right binds everyone who can hinder its exercising not to do it.

Reliance on the theory of absolute and relative rights may become a serious cause for modernization of family legislation on parental rights and obligations, for which a simple generalization and accustomed cataloguing are not already enough. There is a need for their systematization with the account of real social meaning of those of them that are the most significant for the society. Among Russian pearls of wisdom, there is also a catchphrase similar to the one that is used as the keynote of German legislation. This catchphrase belongs to the poet, publicist, and author of the texts of the Soviet Union and the Russian Federation anthems S.V. Mikhalkov "They are Children Today, It is a Nation Tomorrow". The context of this phrase is perfectly in tune with the German one - the future of any nation depends on the way the children are raised, brought up and educated.

The right to educate the child and the child's right to be brought up, to be educated and to develop should be referred to the absolute parental and children's rights. Understanding of the social meaning of these issues broadens them beyond the particular legal relation. Their exercising combines to the fullest extent the private interest and the state interest in ensuring the healthy and decent future society, guarantees of its reproduction, preservation and evolution. Other parental rights can be studied in terms of their relative character and the possibility of their exercising within the legal form of legal relations. These are the rights connected with registration of the child's birth, acquisition (termination) of citizenship, individualization of the child's personality; taking decisions on the issue of religious education of the child and involving the child into religious associations; the issues of providing medical care for the child; the issues of the child's education, the child's marriage before reaching the age of sixteen; exercising of parental rights related to protection of the child's interests. In these aspects, the favorite family legal polemics on correspondence of the established rights and obligations will be suitable. 


\section{Conclusion}

The lack of methodologically based scientific and theoretical groundwork in the study of parental legal relations issues is obvious and pressing. In order to promote the further scientific development of the theory of parental legal relations in its full theoretical scope, it is necessary to pay special attention to the theory of family legal relations. This can lead to the frontier from which one will be able to see the difference in family rights. These rights need differentiation, first of all, with consideration for the state of international constitutional provisions in their human dimension. The achievements of constitutional law and civil law sciences, having come to the division of rights into relative and absolute ones, are deemed to be a solid ground for extending scientific horizons. This will allow for extending the list of legal forms of legal regulation of relations involving parents and children. We should not rule out the possibility that the family law science, with its theoretical achievements in terms of absolute rights, might participate in creating the modern concept of rights "on a par" with other branches of academic knowledge. From our point of view, the requirements of the legislator related to the improvement of legal regulation of parent-child relations are closely connected with the necessity to create the theoretical groundwork for this segment, being socially understandable and, obviously, significant but not free from various legal problems.

\section{References}

1. Braginskiy M. I. O meste grazhdanskogo prava v sisteme "pravo publichnoe - pravo chastnoe» [On the Place of Civil Law in the "Public Law Private Law" System]. Problemy sovremennogo grazhdanskogo prava: Sbornik statey [Problems of Modern Civil Law: Collection of Articles]. Moscow, 2000. Pp. 74-76. (In Russ.).

2. Vorozheykin E. M. Aktual'nye problemy teorii semeynykh pravovykh otnosheniy $v$ SSSR: avtoref. dis. ... d-ra yurid. nauk [Current Problems of the Theory of Family Legal Relations in the USSR: Synopsis of Dr. jurid. sci. diss.]. Moscow, 1973. 33 p. (In Russ.).

3. Dragomiretskaya K. Ya., Zabezhinskaya N. I., Kuzyatina V. E. et al. Sovetskoe grazhdanskoe pravo. Sovetskoe semeynoe pravo. Bibliografiya. 1917-1960. [Soviet Civil Law. Soviet Family Law. Bibliography. 1917-1960]. Moscow, 1962. 664 p. (In Russ.).

4. Zubareva O. G. K voprosu o metodologii issledovaniya semeynykh pravootnosheniy [On the Issue of Methodology of Study of Family Legal Relations]. Semeynoe $i$ zhilishchnoe pravo -
Family and Housing Law. 2015. Issue 4. Pp. 79. (In Russ.).

5. Ioffe O. S. Sovetskoe grazhdanskoe pravo [Soviet Civil Law]. Vol. 3. Leningrad, 1965. 347 p. (In Russ.).

6. Kommentariy $k$ Kodeksu o brake $i$ sem'ye RSFSR [Commentary to the Code on Marriage and Family of the RSFSR]. Moscow, 1982. 296 p. (In Russ.).

7. Kosenko E. V. Otdel'nye formy nauchnogo poznaniya semeynogo prava na primere issledovaniya roditel'skogo pravootnosheniya [The Certain Forms of Scientific Knowledge of Family Rights through the Research of Parental Relations]. Metodologicheskie problemy tsivilisticheskikh issledovaniy: sb. nauch. st.; otv. red. A. V. Gabov, V. G. Golubtsov, O. A. Kuznetsova - Methodological Problems of the Civil Researches: Collection of Scientific Articles; ed. by A. V. Gabov, V. G. Golubtsov, O. A. Kuznetsova]. Issue 2. Moscow, 2017. Pp. 387-404 (In Russ.).

8. Levushkin A.N. Sistema semeynogo zakonodatel'stva Rossiyskoy Federatsii $i$ drugikh gosudarstv-uchastnikov SNG: model' postroeniya $i$ tendentsii razvitiya [The System of the Family Legislation of the Russian Federation and Other State-Participants of the CIS: Model of Construction and the Development Tendency]. Semeynoe $i$ zhilishchnoe pravo - Family and Housing Law. 2014. Issue 3. Pp. 29-32. (In Russ.).

9. Manankova R. P. Poyasnitel'naya zapiska $k$ kontseptsii proekta novogo Semeynogo kodeksa Rossiyskoy Federatsii [The Explanatory Note to the Conception of the Draft of the New RF Family Code]. Semeynoe i zhilishchnoe pravo Family and Housing Law. 2012. Issue 4. Pp. 26-41. (In Russ.).

10. Nechaeva A. M. Semeynoe pravo: aktual'nye problemy teorii i praktiki [Family Law: Current Problems of Theory and Practice]. Moscow, 2007. 280 p. (In Russ.).

11. Nechaeva A. M. Zashchita lichnykh prav nesovershennoletnego grazhdanina $v$ semeyno-pravovoy sfere po Grazhdanskomu ulozheniyu Germanii [Defence of Personal Rights of Underage Citizen in Family Law Sphere According to Civil Code of Germany (Bürgerliches Gesetzbuch, BGB)]. Gosudarstvo $i$ pravo State and Law. 2011. Issue 3. Pp. 86-94. (In Russ.).

12. Pergament A. I. Roditel'skie prava i obyazannosti (leninskie idei i novoe zakonodatel'stvo o brake i sem'e) [Parental Rights and Duties (Le- 
ninist Ideas and New Legislation on Marriage and Family)]. Saratov, 1969. 420 p. (In Russ.).

13. Semeynoe pravo: Bibliograficheskiy ukazatel' dissertatsionnykh issledovaniy (1980-2005 gg.) $i$ nauchnykh publikatsiy (1990-2005 gg.) [Family Law: The Bibliographic Index of Dissertation Researches (1980-2005) and Scientific Publications (1990-2005)]. Kazan, 2007. 262 p. (In Russ.).

14. Sinitsyn S. A. Absolyutnye $i$ otnositel'nye sub"ektivnye prava. Obshchee uchenie i problemy teorii grazhdanskogo prava. Sravnitel'nopravovoe issledovanie [Absolute and Relative Rights. General Doctrine and Problems of Theory of Civil Law. Comparative and Legal Research]. Moscow, 2015. 568 p. (In Russ.).

15. Stepanov S. A. Blesk i nishcheta pandektistiki. $O$ traditsiyakh $i$ netraditsiyakh russkogo grazhdanskogo prava. Vyp. 2 [Splendor and Misery of the Pandect Law. On Traditions and Non-Traditions of the Russian Civil Law]. Problemy teorii grazhdanskogo prava - Problems of Theory of Civil Law. Issue 2. Moscow, 2006. Pp. 146-153. (In Russ.).

16. Tarusina N. N. Rossiyskiy semeynyy zakon: mezhdu konstruktivnost'yu $i$ neopredelennost'yu [Russian Family Law: Between Constructiveness and Uncertainty]. Yaroslavl, 2012. 234 p. (In Russ.).

17. Teoriya gosudarstva i prava: uchebnik; pod red. A. I. Koroleva, L. S. Yavicha [Theory of State and Law: Textbook; ed. by A. I. Korolev, L. S. Yavich]. Leningrad, 1987. 550 p. (In Russ.).

18. Tivodar S. I. Ontologiya semeynogo prava: avtoref. dis. ... kand. yurid. nauk [The Ontology of the Family Law: Synopsis of Cand. jurid. sci. diss.]. Rostov-on-Don, 2000. 23 p. (In Russ.).

19. Chervyakov K. K. Osnovaniya vozniknoveniya $i$ prekrashcheniya roditel'skikh pravootnosheniy po sovetskomu semeynomu pravu: avtoref. dis. ... kand. yurid. nauk [The Bases of Creation and Termination of Parental Legal Relationship According to the Soviet Family Law: Synopsis of Cand. jurid. sci. diss.]. Saratov, 1971. 18 p. (In Russ.).

20. Chernus' N. Yu. Listaya stranitsy nauchnogo zhurnala: istoriografiya semeynogo prava (1927-2010 gg.) [Looking Through Scientific Magazine: Historiography of Family Law (1927-2010)]. Vestnik NGU. Seriya «Pravo»Vestnik NSU. Series: Law. 2011. Vol. 7. Issue 2. Pp. 88-91. (In Russ.).

21. Shakhova E.S. K voprosu o roditel'skom pravootnoshenii v teorii prava [On the Question of Legal Relationships in the Theory of Pa- rental Rights]. Izvestiya Yugo-Zapadnogo gosudarstvennogo universiteta. Seriya istoriya i pra$v o$ - Proceedings of the Southwest State University. History and Law. 2015. Issue 2(15). Pp. 14-19. (In Russ.).

22. Shershenevich G. F. Uchebnik russkogo grazhdanskogo prava [Textbook of the Russian Civil Law]. Part 2. Moscow, 2005. 462 p. (In Russ.).

23. Yavich L.S. Obshchaya teoriya prava [The General Theory of Law]. Leningrad, 1976. 285 p. (In Russ.).

24. Bainham A. Is Anything Now Left of Parental Rights? Responsible Parents and Parental Responsibility. Ed. by Rebecca Probert, Stephen Gilmore, Jonathan Herring. Hart Publishing, Oxford and Portland, Oregon, 2009. Pp. 23-42. (In Eng.).

25. Barrata $R$. The Process of Characterization in the EC Conflict of Laws: Suggesting a Flexible Approach. Yearbook of Private International Law. Vol. VI - 2004. Ed. by P. Sarcevic, P. Volken, A. Bonomi. Sellier European Law Publishers, 2005. Pp. 155-170. (In Eng.).

26. Belohlávek A.J. Rome Convention - Rome I Regulation. Juris Publishing, Inc., 2011. 3086 p. (In Eng.).

27. Broomley's Family Law. Ed. by Nigel Lowe, Gillian Douglas. Oxford University Press, 2015. 1127 p. (In Eng.).

28. Das Grundgesetz (GG) ist die Verfassung für die Bundesrepublik Deutschland. Available at: http://www.bundestag.de/parlament/aufgaben/ rechtsgrundlagen/grundgesetz/gg_01/245122 (accessed 27.07.2017). (In Germ.).

29. European Family Law in Action: Parental Responsibilities. III, Vol. 3. Ed. by K. BoeleWoelki, B. Braat, I. Curry-Sumner. Intersentia NV, 2005. 821 p. (In Eng.).

30. Gerhardt $W$. Absolute und relative Unwirksamkeit als rechtliches Steuerungsinstrument. Festschrift fuer W. Flueme zum 70. Koeln, 1978. Pp. 527-531. (In Germ.).

31. Gilmore St., Glennon L. Hayes and Williams' Family Law. Oxford University Press, 2015. 864 p. (In Eng.).

32. Harris-Short S., Miles J., George R. Family Law: Text, Cases, and Materials. Gosport, 2015. 1144 p. (In Eng.).

33. Kelly W. D. Family Law. Frederick (MD), 2008. (In Eng.).

34. Linde $R$. The Globalization of Childhood: the International Diffusion of Norms and Law against the Child Death Penalty. European Journal of International Relations. 2014. No. (20)2. Pp. 544-568. (In Eng.). 
35. Parquet M. Droit de la famille. Editions Bréal, 2007. 202 p. (In Fren.).

36. Practice Guide for the Application of the Brussels IIa Regulation. Available at: http://ec. europa.eu/justice/civil/files/brussels_ii_practice_ guide_en.pdf (accessed 27.07.2017). (In Eng.).

37. Schellhammer $K$. Familienrecht nach Anspruchsgrundlagen: samt Verfahren in Familien-, Kindschafts- und Betreuungssachen. C. F. Müller GmbH, 2006. 797 p. (In Germ.).

38. Scherpe J. M. Establishing and Ending Parental Responsibility: A Comparative View. Responsible Parents and Parental Responsibility. Ed. by Rebecca Probert, Stephen Gilmore, Jonathan Herring. Hart Publishing, Oxford and Portland, Oregon, 2009. Pp. 43-62. (In Eng.).

39. Vasak $K$. Pour une troisieme generation des droits de l'homme. Studies and Essays on International Humanitarian Law and Red Cross Principles. Ed. by C. Swinarski. Hague. 1984. Pp. 837-845. (In Eng.).

40. Wendel K. Das Recht zur elterlichen Sorge als absolutes Recht i. S. des $\S 823$ Abs. 1 BGB. Available at: http://www.neue-justiz.nomos.de/ fileadmin/neue-justiz/doc/2015/Aufsatz_NJ_15 06.pdf (accessed 27.07.2017). (In Germ.).

41. Westermann H., Westermann H.P., Gursky K. H., Eickmann D. Sachenrecht. Heidelberg, 2011. 1079 p. (In Germ.).

42. Zorn D. Das Recht der elterlichen Sorge: Voraussetzungen, Inhalt und Schranken. Walter de Gruyter GmbH \& Co KG, 2015. 408 p. (In Germ.).

\section{References in Russian}

1. Брагинский М.И. О месте гражданского права в системе «право публичное - право частное» // Проблемы современного гражданского права: сб. ст. М.: Городец, 2000. C. 74-76.

2. Ворожейкин E. M. Актуальные проблемы теории семейных правовых отношений в СССР: автореф. дис. ... д-ра юрид. наук. М., 1973. $33 \mathrm{c}$.

3. Драгомирецкая К. Я., Забежинская Н. И., Кузятина В. Е. и др. Советское гражданское право. Советское семейное право. Библиография. 1917-1960 г. / под ред. И. В. Павлова, Г. М. Свердлова. М.: Госюриздат, 1962. $664 \mathrm{c}$.

4. Зубарева О.Г. К вопросу о методологии исследования семейных правоотношений // Семейное и жилищное право. 2015. № 4. C. 7-9.

5. Иоффе О. С. Советское гражданское право. Л.; М.: Ленингр. ун-т, 1965. Т. 3. 347 с.
6. Комментарий к Кодексу о браке и семье РСФСР / под ред. Н. А. Осетрова. М.: Юрид. лит., 1982. 296 с.

7. Косенко Е. Отдельные формы научного познания семейного права на примере исследования родительского правоотношения. Методологические проблемы цивилистических исследований: сб. науч. ст. Ежегодник / отв. ред. А. В. Габов, В. Г. Голубцов, О. А. Кузнецова. М.: Статут, 2017. Вып. 2. С. 387-404.

8. Левушкин А. Н. Система семейного законодательства Российской Федерации и других государств-участников СНГ: модель построения и тенденции развития // Семейное и жилищное право. 2014. № 3. С. 29-32.

9. Мананкова Р. П. Пояснительная записка к концепции проекта нового Семейного кодекса Российской Федерации // Семейное и жилищное право. 2012. № 4. С. 26-41.

10. Нечаева А. М. Семейное право: актуальные проблемы теории и практики. М.: ЮрайтИздат, 2007. $280 \mathrm{c}$.

11. Нечаева А. М. Защита личных прав несовершеннолетнего гражданина в семейноправовой сфере по Гражданскому уложению Германии // Государство и право. 2011. № 3. C. 86-94.

12. Пергамент А. И. Родительские права и обязанности (ленинские идеи и новое законодательство о браке и семье). Саратов, 1969. $420 \mathrm{c}$.

13. Семейное право: Библиографический указатель диссертационных исследований (19802005 гг.) и научных публикаций (19902005 гг.) / под ред. доц. О. Н. Низамиевой. Казань, 2007. 262 с.

14. Синицын С. А. Абсолютные и относительные субъективные права. Общее учение и проблемы теории гражданского права. Сравнительно-правовое исследование. М.: ИД «Юриспруденция», 2015. 568 с.

15. Степанов C. A. Блеск и нищета пандектистики. О традициях и нетрадициях русского гражданского права // Проблемы теории гражданского права. М.: Статут, 2006. Вып. 2. С. 146-153.

16. Тарусина H. H. Российский семейный закон: между конструктивностью и неопределенностью. Ярославль, 2012. 234 с.

17. Теория государства и права: учебник / под ред. А. И. Королева и Л. С. Явича. Л.: Издво Ленингр. ун-та, 1987. 550 с.

18. Тиводар С.И. Онтология семейного права: автореф. дис. ... канд. юрид. наук. Ростов н/Д., 2000. 23 c.

19. Червяков $K . K$. Основания возникновения и прекращения родительских правоотношений 
по советскому семейному праву: автореф. дис. ... канд. юрид. наук. Саратов, 1971. 18 с.

20. Чернусь Н. Ю. Листая страницы научного журнала: историография семейного права (1927-2010 гг.) // Вестник НГУ. Сер. «Право». 2011. Т. 7, вып. 2. С. 88-91.

21. Шахова E. C. К вопросу о родительском правоотношении в теории права // Известия Юго-Западного государственного университета. Серия история и право. 2015. № 2(15). C. 14-19.

22. Шершеневич Г.Ф. Учебник русского гражданского права. М.: Статут, 2005. Т. 2. 462 с.

23. Явич Л. С. Общая теория права. Л.: Изд-во Ленингр. ун-та, 1976. 285 с.

24. Bainham A. Is Anything Now Left of Parental Rights? // Responsible Parents and Parental Responsibility / ed. by R. Probert, S. Gilmore, J. Herring. Hart Publishing, Oxford and Portland, Oregon, 2009. Pp. 23-42.

25. Barrata $R$. The Process of Characterization in the EC Conflict of Laws: Suggesting a Flexible Approach // Yearbook of Private International Law. Vol. VI - 2004 / ed. by P. Sarcevic, P. Volken, A. Bonomi. Sellier. European Law Publishers, 2005. Pp. 155-170.

26. Belohlávek A. J. Rome Convention - Rome I Regulation. Juris Publishing, Inc., 2011. 3086 p.

27. Broomley's Family Law / ed. by Nigel Lowe, Gillian Douglas. Oxford University Press, 2015. 1127 p.

28. Das Grundgesetz (GG) ist die Verfassungfür die Bundesrepublik Deutschland. URL: http:// www.bundestag.de/parlament/aufgaben/rechtsg rundlagen/grundgesetz/gg_01/245122 (дата обращения: 27.07.2017).

29. European Family Law in Action: Parental responsibilities. III, Vol. 3 / ed. by K. BoeleWoelki, B. Braat, I. Curry-Sumner. Intersentia NV, 2005. $821 \mathrm{p}$.

30. Gerhardt $W$. Absolute und relative Unwirksamkeitalsrechtliches Steuerungsinstrument // Festschrift fuer W. Fluemezum 70. Koeln, 1978. S. 527-531.
31. Gilmore St., Glennon L. Hayes and Williams' Family Law. Oxford University Press, 2015. $864 \mathrm{p}$.

32. Harris-Short S., Miles J., George R. Family Law: Text, Cases, and Materials. Gosport, 2015. 1144 p.

33. Kelly W.D. Family Law. Frederick (MD), 2008. 250 p.

34. Linde $R$. The globalization of childhood: the international diffusion of norms and law against the child death penalty // European Journal of International Relations. 2014. Vol. 20, issue 2. Pp. 544-568.

35. Parquet $M$. Droit de la famille. Editions Bréal, 2007. $202 \mathrm{p}$.

36. Practice Guide for the application of the Brussels IIa Regulation. URL: http://ec.europa.eu/ justice/civil/files/brussels_ii_practice_guide_en. pdf (дата обращения: 27.07.2017).

37. Schellhammer K. Familienrechtnach Anspruchsgrundlagen: samt Verfahren in Familien-, Kindschafts- und Betreuungssachen. C. F. Müller $\mathrm{GmbH}, 2006.797$ s.

38. Scherpe J. M. Establishing and Ending Parental Responsibility: A Comparative View // Responsible Parents and Parental Responsibility / ed. by R. Probert, S. Gilmore, J. Herring. Hart Publishing, Oxford and Portland, Oregon, 2009. Pp. 43-62.

39. Vasak K. Pour unetroisieme generation des droits de l'homme // Studies and Essays on International Humanitarian Law and Red Cross Principles / ed. by C. Swinarski. Hague, 1984. Pp. 837-845.

40. Wende $K$. Das Rechtzurelterlichen Sorge als absolutes Rechti. S. des $\S 823$ Abs. 1 BGB. URL: http://www.neue-justiz.nomos.de/filead$\mathrm{min} /$ neue-justiz/doc/2015/Aufsatz_NJ_15_06.pdf (дата обращения: 27.07.2017).

41. Westermann H., Westermann H. P., Gursky K. H., Eickmann D. Sachenrecht. Heidelberg, 2011. $1079 \mathrm{~s}$.

42. Zorn D. Das Recht der elterlichen Sorge: Voraussetzungen, Inhalt und Schranken. Walter de Gruyter GmbH \& Co KG, 2015. 408 s. 